\title{
INTRAPARENCHYMAL INTRACRANIAL PRESSURE MONITORING IN PATIENTS WITH ACUTE LIVER FAILURE
}

\author{
Alejandra T. Rabadán, Natalia Spaho, Diego Hernández, Adrián Gadano, Eduardo de Santibañes
}

\begin{abstract}
Background: Elevated intracranial pressure (ICP) is a common cause of death in acute liver failure (ALF) and is determinant for decision-making regarding the timing of liver transplantation. The recommended type ICP monitoring device is controversial in ALF patients. Epidural devices had less risk of hemorrhagic complications, but they are less reliable than intraparenchymal ones. Method: Twenty-three patients with ALF were treated, and 19 of them received a liver transplant. Seventeen patients had ICP monitoring because of grade III-IV encephalopathy. All patients received fresh plasma (2-3 units) before and during placing the intraparenchymal device. Results: Eleven cases (64.7\%) had elevated ICP, and 6 patients (35.2\%) had normal values. One patient $(5.9 \%)$ had an asymptomatic small intraparenchymal haemorrhage $<1 \mathrm{~cm}^{3}$ in CTscan, which did not prevent the liver transplantation. Conclusion: In our experience, intraparenchymal ICP monitoring in patients with ALF seems to be an accurate method with a low risk of complications.
\end{abstract}

KEY WORDS: fulminant hepatic failure, hemorrhagic complications, intracranial pressure monitoring.

\begin{abstract}
Monitoreo intraparenquimatoso de presión intracraneana en pacientes con falla hepática aguda
Resumen - Antecedentes: La presión intracraneana elevada (PIC) es una causa frecuente de muerte en la falla hepática aguda (FHA) y es determinante para la toma de decisiones respecto del momento del transplante hepático. El tipo de dispositivo para el monitoreo de OIC es controversial em los pacientes em FHA. Los dispositivos epidurales tienen menos riesgo de complicaciones hemorrágicas, pero son menos confiables que los intraparenquimatosos. Método: Veintitrés pacientes con FHA fueron tratados, y 19 de ellos recibieron un transplante hepático. Diecisiete pacientes tuvieron monitoreo de PIC debido a encefalopatía grado IIIIV. Todos los pacientes recibieron plasma fresco (2-3 unidades) antes y durante la colocación de la fibra intraparenquimatosa. Resultados: Once casos (64.7\%) tuvieron PIC elevada, y 6 pacientes $(35.2 \%)$ tuvieron valores normales. Un paciente (5.9\%) tuvo una pequeña hemorragia intraparenquimatosa asintomática $<1 \mathrm{~cm}^{3}$ en TAC, la cual no impidió el transplante hepático. Conclusión: En nuestra experiencia, el monitoreo intraparenquimatoso de presión intracraneana en pacientes con FHA parece ser un método preciso y con bajo riesgo de complicaciones.
\end{abstract}

PALABRAS CLAVE: falla hepática fulminante; complicaciones hemorrrágicas; monitoreo de presión intracraneana.

Being intracranial hypertension the most common, immediate cause of death in acute liver failure, intracranial pressure (ICP) monitoring has become a procedure of paramount importance ${ }^{1,2}$.

In acute liver failure (ALF), whether fulminant or subfulminant, epidural transducers -although less accurateare currently recommended for ICP monitoring based on their lower rate of hemorrhagic complications as compared with subdural, intraparenchymal, or intraventricular transducers ${ }^{3,4}$.

On the other hand, since the precise knowledge of ICP is determinant for the management of patients with ALF and for decision-making regarding the opportunity of a liver transplantation, we used a highly reliable method for ICP monitoring, such as the intraparenchymal transducer.

The objective of this presentation was to analyse the hemorrhagic complications of ICP monitoring with this type of device in patients with ALF who were candidates for liver transplantation.

\section{METHOD}

We present a consecutive series of 23 adult patients with ALF and encephalopathy. Nineteen of them received a liver transplant (period 1990-2004). Of this series, 17 patients had ICP monitoring because of grade III-IV encephalopathy grade. Thirteen patients had fulminant liver failure, while 4 had sub-

Servicio de Neurocirugía y Unidad de Transplante Hepático, Hospital Italiano de Buenos Aires, Buenos Aires, Argentina.

Received 29 January 2008, received in final form 12 April 2008. Accepted 22 April 2008.

Dra. Alejandra T. Rabadán - Av. La Plata 393 / 8 C - 1235 Buenos Aires - Argentina. 
Table 1. Descriptive data of monitoring.

\begin{tabular}{|c|c|c|c|c|c|c|}
\hline $\mathrm{N}^{\circ}$ & Age & Sex & Monitoring & $\begin{array}{l}\text { Highest ICP } \\
\text { registered }(\mathrm{mmHg})\end{array}$ & $\begin{array}{l}\text { Monitoring } \\
\text { time (days) }\end{array}$ & $\begin{array}{l}\text { PT } \\
(\mathrm{sec})\end{array}$ \\
\hline 1 & 46 & $F$ & Yes & 71 & 5 & 46 \\
\hline 2 & 28 & $M$ & Yes & 22 & 7 & 52 \\
\hline 3 & 22 & $F$ & Yes & 38 & 5 & 70 \\
\hline 4 & 47 & $\mathrm{~F}$ & Yes & 21 & 3 & 34 \\
\hline 5 & 34 & $M$ & Yes & 13 & 2 & 21 \\
\hline 6 & 43 & $M$ & Yes & 12 & 7 & 35 \\
\hline 7 & 27 & $F$ & Yes & 5 & 5 & 25 \\
\hline 8 & 33 & $\mathrm{~F}$ & Yes & 45 & 7 & 41 \\
\hline 9 & 51 & $M$ & No & - & - & 41 \\
\hline 10 & 27 & $\mathrm{~F}$ & Yes & 38 & 4 & 60 \\
\hline 11 & 57 & $\mathrm{~F}$ & Yes & 35 & 1 & 60 \\
\hline 12 & 46 & $\mathrm{~F}$ & Yes & 11 & 4 & 24.5 \\
\hline 13 & 48 & $\mathrm{~F}$ & Yes & 23 & 8 & 42 \\
\hline 14 & 56 & $M$ & Yes & 5 & 2 & 29 \\
\hline 15 & 20 & $F$ & Yes & 53 & 7 & 56 \\
\hline 16 & 24 & $\mathrm{~F}$ & Yes & 10 & 3 & 66 \\
\hline 17 & 24 & M & Yes & 100 & 5 & $>70$ \\
\hline 18 & 57 & $F$ & No & - & - & 67 \\
\hline 19 & 36 & $\mathrm{~F}$ & Yes & 22 & 5 & 63 \\
\hline 20 & 40 & $F$ & No & - & - & $>70$ \\
\hline 21 & 55 & $M$ & No & - & - & 50 \\
\hline 22 & 34 & $M$ & No & - & - & 23.6 \\
\hline 23 & 60 & $\mathrm{~F}$ & No & - & - & 50 \\
\hline
\end{tabular}

$\mathrm{F}$, female; $\mathrm{M}$, male; ICP, intracanial pressure; MAP, mean arterial pressure; $\mathrm{mmHg}$, millimeters of mercury; $\mathrm{PT}$, prothombin time; sec, seconds.

fulminant liver failure. Causes of liver failure were: hepatitis A virus, 3 patients; hepatitis B virus, 3 patients; autoimmune hepatitis, 11 patients; Budd-Chiari syndrome, 1 patient; cryptogenic, 4; and toxic hepatitis, 1 patient (Table 1).

ICP monitoring was carried out with an intraparenchymalmonitoring device, placed by neurosurgeons. Fresh plasma (median, 2 units) was administered before and during the procedure. A twist drill hole was performed, and bone wax, bipolar coagulation of duramater, and generous irrigation were used to provide hemostasis. ICP was considered high when $\geq 20 \mathrm{mmHg}$. Following the insertion of the intraparenchymal device, and due to the severe clinical condition of the patients, computed tomography scan (CT) was only performed if patients present neurological deterioration or new neurological deficit.

\section{RESULTS}

The median age for patients was 40 years (range, 20-60 years). There were 15 women and 8 men. ICP monitoring was carried out in 17 patients, while intracranial hypertension was registered in 11 cases (64.7\%). In 6 patients (35.2\%), ICP was within normal range. The median ICP for the $11 \mathrm{pa}-$ tients with intracranial hypertension was $38 \mathrm{mmHg}$ (range,
21-100 mmHg.). The median time of ICP monitoring was 5 days, ranging from 1 to 8 days (Table 1).

Of this series, 4 patients were not transplanted (one of them with an autoimmune hepatitis who improved at $48 \mathrm{~h}$ ), 2 patients died on waitlist, and 1 patient was not eligible due a persistent intracranial hypertension (100 $\mathrm{mmHg}$ ). In the group of non-transplanted patients, 3 presented intracranial hypertension (Table 2).

All patients had severe coagulopathy. Median prothrombin time (PT) was 50 seconds (sec) (range, 21- >70 sec). PT normal range was considered between 13-17 sec.

As a complication associated with intraparenchymal transducer placement, a symptomatic intraparenchymal bleeding was observed in one patient, clinically manifested by a seizure ( $1 / 17$ cases, $\left.5.88 \%, \mathrm{Cl}_{95 \%} 0.14-28 \%\right)$. CT confirmed the small hematoma. It was localized in the right frontal lobe directly related with the placement site and the volume was approximately $1 \mathrm{cc}$. The small volume of bleeding did not impede the liver transplant, which was carried out uneventfully. The cerebral hematoma resolved spontaneously without neurological consequences. 
Table 2. Descriptive data of pathology.

\begin{tabular}{cccc}
\hline No & Hepatopathy & Encephalopathy & Transplant \\
\hline 1 & Autoimmune & grade III & Yes \\
2 & HBV & grade III-IV & Yes \\
3 & Cryptogenic & grade III-IV & Yes \\
4 & Toxic & grade IV & Yes \\
5 & Cryptogenic & grade III & Yes \\
6 & Autoimmune & grade III & Yes \\
7 & Cryptogenic & grade IV & Yes \\
8 & Cryptogenic & grade III-IV & Yes \\
9 & Autoimmune & grade II-III & Yes \\
10 & Autoimmune & grade III & Yes \\
11 & HVA & grade III-IV & Yes \\
12 & Autoimmune & grade IV & Yes \\
13 & HVA & grade IV & Yes \\
14 & Autoimmune & grade IV & No \\
15 & Autoimmune & grade III-V & No \\
16 & Autoimmune & grade IV & Yes \\
17 & HBV & grade III-IV & No \\
18 & HBV & grade II & Yes \\
19 & Budd-Chiari & grade III & Yes \\
20 & Autoimmune & grade II-III & Yes \\
21 & HVA & grade II & Yes \\
22 & Autoimmune & grade II & Yes \\
23 & Autoimmune & grade II & Yes \\
\hline HVB & A & \\
\hline
\end{tabular}

HVB, hepatitis B virus; HVA, hepatitis A virus.

CT will be doing if the patient is on transplant list or if he had encephalopathy I-II with a new focal deficit or if ICP is elevated.

\section{DISCUSSION}

The advent of liver transplantation as a treatment option for ALF requires also the management of associated hepatic encephalopathy. Diagnosis and monitoring of intracranial hypertension contributes to the care of candidates for liver transplantation, both before and during the surgical procedure. Nevertheless, in the case of patients with ALF, it is important to consider the disadvantages related with the use of an invasive method, not only because of the severe disorders of the coagulation, but also because of the immunological compromise associated with this type of pathology ${ }^{1-3}$.

In the common neurosurgical practice, ICP monitoring can be performed using intraventricular, intraparenchymal, subdural, or epidural devices. The intraventricular transducer is widely accepted as the "gold standard system" for ICP monitoring, being its main complication the bacterial colonization with an incidence of up to $40 \%$. In patients without coagulopathy, the reported incidence of hemorrhagic complications was $1.1 \%$, and the incidence of the device malfunction was $6.3 \%$. Intraparenchymal transducers are currently most used because the procedure of placement is very easy and it is associated with a low rate of complications. The main disadvantage is the dysfunction of the optical fiber (9-40\%). The hemorrhagic complication is observed in $2.8 \%$ of the cases, and the incidence of bacterial colonization has been brought down to $0-14 \%$ of the cases $^{5-7}$. In a prospective study of intraparenchymal monitoring, haemorrhage was observed in $2.1 \%$ of patients without alteration of the coagulation, and in $15.3 \%$ of their counterparts with coagulopathy ${ }^{8}$. In another study, 118 patients with intracranial pathology but without coagulopathy were evaluated, and the incidence of observed complications was: infection (0.7\%), intraparenchymal haematoma (5.1\%) and complications related with technical aspects $(23.5 \%)^{9}$. Subdural devices present an infection incidence of $4-5 \%$, whereas the risk of haemorrhage is extremely low ${ }^{6,7}$.

In ALF, the election of the type of ICP monitoring is very important owed to the high risk of bleeding attributable to the basal coagulopathy. The majority of authors recommend the epidural monitoring as a safer procedure, in spite of its lower accuracy ${ }^{3,10}$. Blei et al. reported a series of patients with ALF, with a lesser index of complications (3.8\%) with the use of epidural transducers, compared with complications observed with subdural and intraparenchymal devices, which presented a procedurerelated bleeding incidence of $20 \%$ and $22 \%$ respectively. Fatal haemorrhage occurred in $1 \%, 5 \%$, and $4 \%$ of patients with epidural, subdural, and intraparenchymal monitors, respectively ${ }^{1}$. In a study of 36 patients with intracranial hypertension and encephalopathy grade IV, Keays et al. reported few complications, including bleeding at the placement site of epidural ICP transducers ${ }^{3}$. The Mayo Clinic group published an analysis of 11 patients with ALF and ICP monitoring using subdural devices, showing only one patient presenting a complication, a focal haemorrhage secondary to the transducer placement ${ }^{11}$.

Since the first report in 1993, the majority of the centers use epidural transducers in patients with acute liver failure in order to avoid hemorrhagic complications ${ }^{3}$. The first patient of our present series was treated in 1990 with intraparenchymal device, and following this case, the procedure continued in the same way. We are reporting a retrospective study, and we would like to emphasize that the present communication is focused on the technical aspects and not on the management and effectiveness of the treatment of intracranial hypertension. In our series, we used intraparenchymal transducers to privilege 
the accuracy of ICP monitoring for patients with ALF. The monitor used was Camino Inc, and no malfunctions of ICP devices occurred in this group of patients. Prevention of complications was performed by prophylactic administration of periprocedural fresh plasma, and by the placement of devices done by neurosurgeons in all cases. The procedure was a blind insertion via a twist drill hole. It was carried out by neurosurgeons in the Intensive Care Unit. Coagulation was used to control bleeding.

In our series, the incidence of complications was similar to that obtained by other authors who utilized subdural or epidural transducers. No infectious complications were observed, and the median ICP-monitoring time was 5 days (range, 1-8 days).

In conclusion, based on our experience we can suggest that intraparenchymal ICP monitoring in patients with ALF is a precise method, with a low risk of complications. The possibility of hemorrhagic complications at the placement site is similar to patients without coagulopathy with the appropriate prophylactic treatment.

\section{REFERENCES}

1. Blei AT, Olafsson S, Webster S, Levy R. Complications of intracranial pressure monitoring in fulminant hepatic failure. Lancet 1993;34:157-158.

2. Jalan R. Intracranial hypertension in acute liver failure: pathophysiological basis of rational management. Semin Liver Dis 2003;23:271-282.

3. Keays RT, Alexander GS, Williams R. The safety and value of extradural intracranial pressure monitors in fulminant hepatic failure. J Hepatol 1993;18:205-209.

4. Raabe A, Totzauer R, Meyer O, Stockel R, Hohrein D, Schoche J. Reliability of epidural pressure measurement in clinical practice: behavior of three modern sensors during ipsilateral intraventricular or intraparenchymal pressure measurement. Neurosurgery 1999;44:920.

5. Smith RW, Alksine JF. Infections complicating the use of external ventriculostomy. J Neurosurg 1976;44:567-570.

6. Holloway KL, Barnes T, Choi S, et al. Ventriculostomy infections: the effects of monitoring duration and catheter exchange in 584 patients. J Neurosurg 1996;85:419-424.

7. Shapiro S, Bowman R, Callahan J, Wolfla C. The fiberoptic intraparenchymal cerebral pressure monitor in 244 patients. Surg Neurol 1996;45:278-282.

8. Martinez Mañaz RM, Santamarta D, Campos JM, Ferrer E. Camino ${ }^{\circledR}$ intracranial pressure monitor: prospective study of accuracy and complications. J Neurol Neurosurg Psychiatry 2000;69:82-86.

9. Munch E, Weigel R, Schmiedek P, Schurer L. The Camino intracranial pressure device in clinical practice: reliability, handling characteristics and complications. Acta Neurochir (Wien) 1998;140:1113-1119.

10. Smith $\mathrm{W}$, Aminoff $\mathrm{M}$. Introduction to monitoring in the neurological intensive care unit and its future impact. Neurologist 2000;6:83-97.

11. Daas M, Plevak DJ, Wijdicks EF, et al. Acute liver failure: results of a 5year clinical protocol. Liver Transpl Surg 1995;1:210-219. 